\title{
The Nigerian Entertainment Industry (Nollywood) Culture and Society Being
}

\author{
Yosi Apollos Maton \\ Deputy Provost of the Theological College of Northern Nigeria, Nigeria \\ The University of Jos, Nigeria
}

Copyright $\bigcirc 2018$ by authors, all rights reserved. Authors agree that this article remains permanently open access under the terms of the Creative Commons Attribution License 4.0 International License

\begin{abstract}
The fight for independence was carried out with a lot of zeal, which the populace embraced with high hopes that these ideologies and promises of our great nationalists would come to fruition within the shortest time possible. Yet, times, opportunities and years have come and gone, still we have nothing or little to show, especially, in the $21^{\text {st }}$ century scenario, where Africa dreams and hopes have been shattered. These ideologies seem unrealistic and the promises are not forth coming. It has little to show except bad governance, crisis, violence, poverty, oppression, marginalization and the moral decay of our rich cultural values and societal structures. One is left with the vexing questions: Where have our great nationalists gone wrong? If indeed their ideologies and promises were realistic, why have the people not grasped their vision and mission, especially the case of the Nigerian entertainment Industry (Nollywood)? Why is it that their creativity promoting very little of these ideologies? Why do they still portray the mentality that they are still puppets in the hands of the colonial master since most of their creativity promotes little of our rich positive cultures and values? Are they not aware that they have tools in their hands that can go a long way to promote those ideologies and fulfill these promises and fan the flame of nation building and promotes its cultural heritage and values until we are there? Why must this great and powerful tool be used as agent of destruction of the Nigerian society and its rich cultural values? Can't they think of lasting legacies that posterity can tell? The paper looks at the brief historical and geographical background of Nigerian society, its ethnic groups and its cultures, then went on to discuss Nollywood and her role in consolidating the development of the Nigerian society and its Cultures. It then went on to look at factors that militated against the effectiveness of Nollywood in promoting national development and cultures. The paper then profers ways forward and round up with a conclusion.
\end{abstract}

Keywords Entertainment Industry, Culture, Values, Society and Development

\section{Brief Historical Background and Geography of Nigerian Society and Culture}

Before the advent of colonialism what is known as Nigeria today was not in existence, rather Kingdoms or empires that had existed as separate of entities were in existence. They had governmental structures of their own. These separate entities were later lumped together into one nation, therefore it became united nation at independence in 1960; but there was still need for nurturing' and reinventing ways to build it' because of its diversity [3]. These diversities instead being blessings have become great hindrances to their progress, development and unity of the new nation.

The amalgamation of Nigeria into a nation happened on the 1914, the North, East and Western parts of Nigeria were formed into one entity without consultation with the natives, to the advantage colonial masters. They ruled the natives through "indirect rule". It was a system of "divide and rule system of government; [4] (Madiebo 3), while the different kingdoms still governed themselves and controlled the resources of their regions but reported to the colonial masters. This way, the colonial masters exploited both the human and material resources of the nation to their own advantage (Madiebo 3). The colonial masters felt nothing was wrong with their actions. Even their missionaries justified colonialism, that colonialism was a blessing because by mere fact that the natives that were subjugated under the colonial masters had the opportunity of coming under the rule of Christ, it is a blessing [5] (Boer 45). They did not see colonialism as an instrument of the destruction of the rich cultural heritage of the Nigerian societies. In their own eyes and experiences, colonialism offered a more superior culture. So even though colonialism abolished slavery, ended inter-tribal wars, built roads, railways and river steamers and imposed the principle of "peace, trustee and prosperity" (47) it was a case of "robbing Peter to pay Paul"; because on one hand they stopped some injustice, but were perpetrating 
injustice on the other hand by destroying their societies and cultures. They were enslaving the natives through suppression and forceful domination and siphoning their resources to build their countries.

This system of government did not encourage the establishment of Nigeria as "one homogeneous Country" (3) rather it differentiated, discriminated, and marginalized peoples among themselves thus, Madiebo says it led to "social apartheid "(3); it led to division, hatred, unhealthy rivalry and pronounced disparity in development among the various people of the Country" (4) and completely destroyed their cultures. It was rather a system that greatly helped the colonial masters because it broke the power of people to resist them, because they did not have collective power to resist their domination (4). How did the system work?

The Hausa-Fulani in North accepted the indirect rule on the condition that colonial masters must not allowed any other "religion, culture and customs" to infiltrate their communities to which they agreed. This further alienated the South from the North, thus further compounded state of disunity among the people. Not only that resources sharing formula and appointments tend to favour the North more than the South East and West (4). Not only that the natives under the caliphate lost their indigenous cultures, distinctiveness and even their system of governance to the Northern Imperialists. They were enslaved and subjugated and the result is the unending conflicts that characterized the North East, North West and the Middle-belt of Nigerian societies. These differences greatly affected the political climate and culture of the Nigerian society. As Madiebo posited that, "nationalism and political parties in Nigeria then were based on tribal and regional interests rather than national interest, thus he maintained that the nationalists did not have a strong and united voice against the colonial masters (4-5).Unfortunately, this has become the legacy that characterizes the Nigerian political system, tribalism and regional interest with lopsided appointment into parastals favouring only the region and tribe that has the power, thus, the federal character has never been observed.

Burns[6] states that Nigeria is 373,000 square miles and is bounded in the north by the desert, in the south coast land which is a thick forest and swamp. Its boarder to the west is the gulf of Guinea, while its boarder to the east is Cameroon (13). The climate of Nigeria is hot and humid and has a lot of insect -borne diseases like tsetse flies and mosquitoes (13). Nigeria has 36 states and these states are divided into six geo-political zones [7] during the era of General Sani Abacha. They are the North East, North West, North Central, South West, South East and South- South. The North East geo-political zones comprises of Bauchi, Borno, Yobe, Adamawa, Gombe and Taraba. The North West geo-political zones comprises of the following states, Jigawa, Kaduna, Kano, Katsina, Kebbi, Sokoto and Zamfara. North Central geo-political zonal states are Niger, Kogi, Benue, Plateau, Nasarawa, Kwara and the Federal Capital Territory. The South East geo-political zone comprises Abia, Anambra, Ebonyi, Enugu, and Imo States. The States in the South-Western geo-political zones are Oyo, Ekiti, Osun, Ondo, Lagos, and Ogun, while the South-South geo-political zonal states are Bayelsa, Akwalbom, Edo, Rivers and Cross River.

Somunmi [8] reported in the Vanguard Newspaper of $10^{\text {th }}$ May 2017, that Nigeria has about three hundred and seventy-one tribes or ethnic groups. However, his research is not conclusive because there is strong indication that there are more than four (400) hundred ethnic groups in Nigeria. This is so because from his report, there are other tribes that were not recorded in his findings within my state such as Fyer, Tal, Chakfem, Mupun, Tarok etc. And if from a glance I can notice this lapse, it goes to say that there are many other tribes from other states that are not recorded, thus I conclude that the list of tribes listed according to Somunmi's report is not exhaustive. However, Lewis et al gave a figure of about 450 and above which further confirms my assertion that there are more than four hundred ethnic groups in Nigeria .For the purpose of this discussion I am using 450. Out of the four hundred and fifty ethnic groups there are three major tribes in Nigeria who are dominant; they are Hausa-Fulani, Yoruba and Igbo tribes. Meek [9] in his preface acknowledged that there are minor tribes in the North and middle belt of Nigeria who are non-Muslim but speak Hausa as lingua franca for easy communication due to the dense diversity of these ethnic groups whose language are completely incomprehensible to the other.

The Hausa-Fulani ethnic groups are found in Borno, Yobe, Jigawa, Bauchi, Nothern Kaduna, Kano, Katsina, Kebbi, Niger, Sokoto and Zamfara. They are called the Hausa-Fulani because Othman dan Fodio jihad subjugated most of the Hausa stock and forced them to accept Islam, thereby destroyed their customs, culture, institutions and their religion. Since majority of them embraced Islam, there was intermarriages among them and so they became integrated (Burns 41). According to Burns submission, these Fulani migrants migrated from Upper Egypt (45), while Crowder asserted that they migrated from Senegal River Valley and came and waged war against the Hausa Empire [10] (92-93). One thing is clear from these submissions; the Fulani were not from the Nigeria. They migrated from North Africa through the trans-Sahara trade route and came and disposed the Hausa indigenes and occupied their land through jihad.

However, it is worthy of note to know that there are still some remnant of pure Hausa stock who did not embrace Islam and still maintain their culture and language e.g. the Maguzawa and those from Zurru inKebbi and Sokoto States, Nigria'. Also in these Hausa states there are still other minority tribes who are not of Hausa-Fulani stock, e.g.Za'ar in Bauchi State and Tangale in Gombe State. It is not true that in all the States where the Hausa-Fulani are found today, they are the only tribes there; rather there are still other minor tribes whose cultures and languages are living. A casual observer is always deceived by the fact that 
almost everyone speaks Hausa and feels that all are Hausa. This line of thinking and argument becomes irrational if place alongside with the argument that says everyone that speaks English in a Briton. The major concern is that the minor tribes living among the dominant tribes are often oppressed, subjugated, marginalized and discriminated against politically, socially, economically, culturally, language-wise and religious-wise simply because they are the minority in the state.

The next major tribe in Nigeria is the Yoruba tribe (Burns 22). They are found in Lagos, Ogun, Ondo, Oyo, Osun, Ekiti, Kwara and Kogi State. They are the dominant tribes in these states. As observed in the preceding discussion on the Hausa-Fulani, there also minority tribes in the predominant Yoruba states. It is a faulty assertion to assume that they are the only tribes in those states simply because everyone there speaks Yoruba. For instance state like Lagos and Kogi states have other minority tribes living alongside these dominant tribes. The only concern is that the minor tribes are often suppressed, marginalized and discriminated against politically, socially, economically culturally and religious-wise. They are usually forced to learn the language for communication yet their own language and cultures are living because they still speak and practice them.

The third major tribe is the Igbo tribe. They are found in Abia, Anambra, Delta, Ebonyi, Enugu, Imo and Rivers States. This tribe is found in the South Eastern part of Nigeria. They speak one common language and have similar culture. However, even though they are the dominant tribe because of their population it does not go to say that they are the only tribes in those states, but there are other minor tribes living among them. Burns in his book recognizes other tribes in Nigeria other than the major tribes (22), even though his list is in-exhaustive, but as per the time he was writing he was conversant with these ones. Tony on his report recorded three hundred and seventy-one ethnic groups, but as I have earlier mentioned, his list too is not exhaustive. Apart from these three major tribes, there are other minor tribes found in the South-South, North East, North West and North Central geo-political zones. Therefore going by Lewis et al report, the Yoruba, Hausa-Fulani and the Igbo are only four out of the four hundred and fifty tribes in Nigeria, which represents only $0.9 \%$ of the tribes and cultures in Nigeria. The bulk of the tribes which is four hundred and forty-sixty and their cultures form the $99.1 \%$ of the tribes and cultures of the Nigerian society which are still untapped.

Furthermore, due to the diversity of the ethnic groups in Nigeria, the language and cultures in Nigerian society are quite diverse. Sometimes a casual observer tends to think that Nigeria is made up of only of these four ethnic groups because of their dominance, but of a truth they represent only $0.9 \%$ of the tribes and consequently the cultures in Nigeria. They have dominated most of the geo-political zones of Nigeria politically, economically and socially because of their populations but not because their tribes are the majority, rather the minority tribes are more than them in number. Their dominance in population has spilled over into the international communities to some extend that they mistake them to be the only ethnic groups in Nigeria, yet they are only but a very small insignificant fraction as compared to $99.1 \%$. Not only that the amalgamation of Nigeria into one entity has done more harm than good to the minority tribes. In the north and central zones Adandele [11] submits that they lost their customs, cultures and indigenous religion (11), while in the south the other minority tribes' identities were overshadowed.

\section{The Role Nollywood in Consolidating Cultural Heritage of Nigerian Society}

There is no gain say that Nigerian Films Industry occupies a very important role in national development of the Nigerian Society and its cultures. Film is a mean of communication with a universal appeal and impact [12]. Film is "visually bias for it holds its audience captives and it is a link between all other forms of literature i.e. "prose, poetry, short stories, and drama" (Ibid). Television came into being in 1959 through the initiative of Chief Awolowo who wanted to tell the world his own side of the story of the conflict between him and McPherson, the colonial Governor of Nigeria, who refused him the usage of the Nigerian Broadcasting service (NBC) thus he brought into being the first Television station in Nigeria and African, NTA Ibadan [13] (Dali 38).

Since film is a subtle and powerful tool in passing information across to people and creating an image both domestically and internationally, government had often used it to communicate to their audience. The best example is the United Arab Emirate (UAE), though it is monarchical Kingdom with a totalitarian system of government but it engaged Hollywood producers in 1990 to project a positive image of the government to the world. They insisted that the films portray positive and good cultural values of the nation. [14] This submission is also supported by Okoye who quoted Prof. O. Enoch as saying that "colonial administrators used movies to accelerate development in their various colonies." [15] So there is no doubt that visual communication has a very strong appeal for the development of any nation.

Dias [16] posited that film and "Cinema being an art form is a non-threatening medium through which human values can be communicated (91). He numerated those values like "selflessness, unconditional love, love for enemies, reconciliation, and care for the underprivileged" (91) can be communicated through films and cinema. This is certainly true and in addition to these values like stewardship, transparency and accountability, honesty and truthfulness, "non-violence, tolerance, love and peace" (97) 
can be communicated. This is so because Adenugba stated that "we learn much more through what we hear and see." This is a universal truth which education has established among children that they learn more through what they see thus films holds its audience captive (Ibid).

This background already makes it clear that film industry is very important in the making of Nigerian society and cultures. The first important role of films or movies is that it is a change agent because it has the power to harness the potentials within the nation. Adenugba concurred also, that film "play important roles in the development of any group of people, ethnicity, and races as a nation or country" (Adenugba 2008). He went on to state that film is "an institution where cultural values, development initiatives and aspirations are propagated (Ibid). He further posited that film Industry is "major driver of economic growth and job creation, if the potential inherent in the sector are adequately harness". He said it is through it "cultural heritage, political needs and aspiration of the people are highlighted. He went on to say that film promotes and unites various socio-cultural groups in the nation.

Another important value of film industry is that it preserves cultures from eroding, and protects and promotes rich cultural heritage and national aspiration of people that is "marriage, costumes, dressing, music, burial practices" (Adenugba Ibid). Adenugba went on to narrate how film industry protects, promotes and transports the cultures of Indians and America across the globe through Bollywood and Hollywood (Ibid). Film also helps in education and human resources development, thus Adenugba said films today feature different professions e.g. medicine, law, management task, agriculture etc. (Ibid). He further said film enlightens people on phenomenon in the environment (Ibid) e.g. Issue of global warming are vividly displayed through films to drive home the message.

Film is a means of propaganda because it sells the government to the people and helps in projecting government policies (Ibid), thus it plays a very important role in social mobilization and information dissemination. It is a tool for popularization of government policies and since most films are played through the medium of television screens, one can effectively present" one's agenda and issues" (Ibid) through this means. Adenugba further said, film "is a tool of national mobilization, unity, a sign of national autonomy and a means of preservation of heritage and sovereignty" (Ibid). He went on to state that film also helps in relaxation and relieving tension and he gave examples of films like "The gods must be crazy (Bushman) and "Wukwa" (Ibid). Since film industry plays a very significant role in the making of nation like this what role has Nollywood played thus far in the making of Nigeria as a nation and in the consolidation of independence in Nigeria and preserving its cultural heritage?

The Nollywood is said to be third largest industry in the world due to its reputation of telling stories in "creative and innovative ways" (Okoye). However, to what extend has it helped towards national development and preserving the rich cultural heritage of Nigeria? One of the most remarkable contributions of Nollywood towards national development of Nigeria as a nation according to Okoye is that it "provided platform for the emergence of various entrepreneurs" (Ibid), thus bridging the gap between poverty and unemployment. This is true in the story of a 32 years old chemistry graduate Jason Njoku who became the largest distributor of Nigeria movies and he was said to accrue 8 million Naira in 2010. [17] She went on to narrate the story of Njoku, that at that time he had 71 employees in Lagos, London and New York (Ibid). World Assessment of Rich People by Forbes placed Njoku among the top 10 millionaires during that time (Ibid).

Secondly, Nollywood industry has led to the economic growth and development of Nigeria as nation. Moundo said Nollywood, which is second only to Bollywood and Hollywood, produces 50 movies per a week (Ibid) while Norimitsu [18] said, in a year Nollywood produces 2500 movies and this has helped in providing employment to many people and generated millions for Nigerian as income. That Nollywood contributes $\$ 600$ million yearly into the nation's economy, as per the time of filing in this report, while 400 movies were sold at $\$ 45$ million (Norimitsu 2016).

Thirdly, Nollywood has also helped in exporting Nigerian cultures across the globe, its music, comedy, fashion, religion, lifestyle and everything (Ibid). Moundo said this has greatly made Nigeria very popular in the continent. This position also found support from Okoye submission that Nollywood has promoted Nigeria to its greatness, thus it is said to be "the Giant of Africa." He said the industry has "showcased the creative ingenuity of actors and actresses", thus it has become a "player in global audio-visual industry, and boosted the image of the country globally."

Some films and movies that greatly impacted the life of Nigeria as a nation and promoted her sovereignty and cultures were George Mentas TV series, "Cock Crows at Dawn." [19] The other films are "My Father's Burden" by Wole Soyinka. This film made bold statement on public morality where corruption has become an acceptable norm in the society. [20] Next, is "The Village Headmaster", Nigerian TV series "Super Story", "The Cry of an Orphan", "The Voice of the Orphans, "Worlds Apart", "the Human Trafficker," "Mr. Ugezu's Story of an African Prince's Choice of a Bride" The movie according to Norimitsu portrayed "a precolonial past and a present caught between village life and urban modernity. The movie explores the tensions between individual and extended families, between the draw of urban life and the pull of the village, between Christianity and traditional beliefs. For countless people, in a place long shaped by outsiders, this film by Nollywood is redefining the African experience etc. These 
films speak volumes about cultures and social ills and injustice in the family, and society e.g. the Human Trafficker, it features the biggest modern problem in our society i.e. slavery, prostitution, and child trafficking and kidnap, poverty, corruption, mafia, and crime syndicate. [21] Thus, Communication technology (Television), "has improved social, economic, political and cultural pattern of Nigerians" (Dali 32). In spite of this great stride by the Nollywood, why is Nigerian society still bankrupt educationally, culturally, economically, socially and politically? Why have the hope, dreams and aspirations of Nigerian citizenry not yet been attained? What must have gone wrong?

\section{Factors that Militate against Effective National and Cultural Development of Nigerian Society by Nollywood}

Notwithstanding the enormous progress Nollywood has made globally Mba [22] says Nollywood is "albeit an industry in disarray" which according to him, needs serious reformation to be able to contribute to the economic, cultural and political development of the Nigerian society (2). He says the industry faces competition both within and outside, host of them are due to piracy. That though digital technologies make film - making easy and fast, yet the same digital technologies also make it easy to copy someone's work and distribute it on-line through person to person and home through video (2). Erick also concurs that 'rampant piracy has limited international trade and investment for Nollywood, especially through local distribution pirates. These local distributors succumbed to the demands made by Diasporas to distribute their works illegally; thus even though their films and movies are watched all over the world yet the income does not come to them and the government because of piracy's (1-2). Information Technology (TV) has "socio-political, economical, religious and cultural implications," [23] (Maton 68) that though it passes information on to its audience, but most of these information are not authentic thus, socially and culturally youths and children copy role models that undermine traditional and cultural roles models in the Nigerian society. Not only that cultural values that are foreign to the Nigerian society are imported into Nigeria which undermine traditional institutions like sex, marriage family life and African communal life and community ethics. Economically it promotes trade, but only the multi-nationals tends to benefit (68-69) for instance a case of the Nigerian film industry where they make far less than their counter parts in Hollywood.

Adenugba said ineffectiveness of Nollywood can also be attributed to inadequate funding, poor structures, poor distribution and marketing affects the industry. He said, this is further worsened by government negligence of this great tool for development. Even where she is aware of the role of film in national development it has not properly harnessed the tool to its own advantage except for the era of Gen. Babangida. He conveyed the first national film conference in 1994 and processed the establishment of national film Censor Board and National film institute in Jos, Since then, none of the Nigerian leaders has taken special interest in the film industry until recently in the time of President Good Luck (Adenugba2008).

Adenugba further said, since government showed little support towards the industry by failing to fund, facilitate the production, distribution and its exhibition, there was no valid and appropriate policies and laws to safeguard the industry. Lack of laws and polices made piracy to thrives thus both the producers and the government are losing millions of economic income to their activities (lbid). He further stressed others factors that contribute to the ineffectiveness of Nollywood towards National development, as the proliferation of Nigerian entertainment sector with foreign films and movies. $\mathrm{He}$ said since the $80 \mathrm{~s}$ and $90 \mathrm{~s}$, more than $50 \%$ of the Nigerian broadcast programs were foreign rather than local and home grown programmes and movies. He said this set the stage of re-colonization of Nigerian educational programmes, wearing of western garbs (lbid) and the importation of foreign cultures that are harmful to the Nigerian society and its cultures, thus our cultural heritage are eroding (ibid) because the younger generation are copying western role models instead of role models from the Nigerian society.

This trend did not stop with the importation of foreign films, but even the Nollywood itself loses focus of her vision and mission. She began to produce "Europeanized Nigerian movies and films" projecting, promoting and importing foreign cultures and values (ibid), knowing fully well as Dias posited that films "supply people with opinion and ideas on every subject" (93). They failed to consolidate and build relationships between cultural and ethnic groups in Nigeria, nor did they concentrate on issues that are of national concern (ibid) to the Nigerian society, i.e. HIV/AIDS endemic, corruption, unity in diversity, poverty, environmental pollution, good governance, global warning etc. The repercussion of it is that our young viewers and illiterate audience, who had no ability to discern in-depth and separate reality from falsehood, became gullible thus the instrument which supposes to be agent of change and transformation became the instrument of destruction of the Nigerian society and its cultural heritage and future generation.

They failed to project heroes and heroine in our society to inculcate the spirit of patriotism in the young ones. The resultant effect is that our fragile socio-political structure is further weakened and hampered because there is no effort directed toward national unity, positive social mobilization and transformation, thus their production now lacks appeal and relevance to the Nigerian society. They now dwell 
more on negative cultural practices such as witchcraft, pornographic films, materialism, vampire, cults, secret societies, wickedness, mafia and violence, thus the young and illiterate viewers are motivated towards those line of thinking, while the older generation lose faith in its relevance for the development of Nigerian society.

They did not properly harness the rich cultural heritage that Nigeria has since it is a multi-cultural society with quite diverse ethnic groups and cultures, thus they are unable to effectively promote "humans' progress" (Mba 6), as the case of Bollywood and Hollywood. These lapses are further worsened by lack of government sponsorship and funding. This makes producers produce low quality products that have little bearing on the socio political and cultural life of the people. Poor performance is also attributed to lack of "peer review mechanism or certified apprenticeship" (Mba 2). For them to produce films that would have lasting impact on the Nigerian society, they need these structures on ground. Another factor that led to its ineffectiveness towards social transformation and development is lack of laws to regulate piracy and copy-right law, coupling with lack of infrastructure like light and power grids (Erick 1-2). This made their performance to fall below expectation.

Lastly, internet and digital technologies present the challenge of distributing the content to the wider audience. In their attempt to create content that are consumable by wider audience, they began to drop most of our cultural values for western cultures and values (Mba 2) therefore end up being irrelevant in the development of Nigeria as a nation. In addition to that, new technologies require experts who are skilled at it to handle. Since skilled hands are not available in Nigeria, film producers in Nigeria have to rely on foreign experts for their productions thus Mba said, they ended up being industry that is "distribution-led, not production led" (5) because the films are produced and edited from outside the country and are distributed by the Nigeria. Often times the producers tend to influence the content of the film not minding the audience. Apart from that, they become easy prey to pirates who steal their labour and make fortune from them. If this the state of the Nollywood industry, what then can be done to reposition her in the making of Nigeria as a nation? What is the way forward towards revitalizing the industry for effective national and cultural development?

\section{Towards Revitalizing Nollywood for Effective Nation Building and the Preservation of Nigerian Cultural Heritage}

Since it has been established that film industry is a very powerful tool in selling government agenda and policies as well as nation building, yet both government and films producers have not properly harnessed this great tool. It is in this respect that Mba said, there is need for the government to work hand in hand (1) now with the industry to promote its agenda and policies. Doing so would not only promote and project their agenda and policies, but it could generate a lot of income for the country and create more employment opportunities for our unemployed teaming youths, especially if it is properly managed [24] (Madichie).This is to help stop brain drain to the west, which is another form of neo-colonialism.

Okoye on his part said, the producers of movies should aim at producing movies that "consolidate the growth of the industry by making movies that border on promotion of National interests (Okoye 2014). They should aim at producing movies that "foster economic, cultural, social and political consciousness of the people so as to give voice on how best to increase development (ibid) rather than borrowing foreign cultures and values, which is another form of colonialism which speaks loud and negatively of the industry and Nigeria itself because it portrays bankruptcy of initiative, creativity and innovation. After all, who succeeds in a venture if he/she ends up producing a copy of another person's venture?

The third thing that needs to be done is that the film industry needs to be "pro-active in promoting essential cultural components" (Adenugba2008) of the Nigerian society instead of foreign ones. In their case, since Nigeria so rich with a lot of cultures, they should explore positive cultural values in other tribes rather than concentrating only on the same geo-political segments cultural values (Hausa-Fulani, Yoruba and Igbo). Are these the only ethnic groups in Nigeria? What about the $99.1 \%$ of the minor tribes which make up the bulk of these three ethnic groups put together? [25] (Price 68). In fact, they should see these cultures as blessings to the industry which they need to explore, thus they cannot be bankrupt of initiative, creativity and innovation, rather booming in the industry since their well will never runs dry because of the diversity of the ethnic groups therein.

There is urgent need for the industry to have leadership, structures and accountability. Mba says such leader must be pragmatic and creative. Leaders who have a driving force to make film, not those who only have passion for it $(3,5)$. He went on to state that the industry must have "a well thought out plan for how to market their products (5) rather than producing films with no clue on how to market and distribute it. Not only that he said, there is need for them to strike a balance between the realities on ground and current challenges on ground, bridging the gap between cultures and modernity (5), and in addition to that use their experiences in film making and produce good stories. Unless the industry works on these lapses the industry is working towards self-destruction.

Furthermore, they must have innovative spirit and adventure to go beyond where they are. They must tell good stories by studying the subject, be passionate, be willing to accept failure and learn; watch both homemade 
and foreign films, new and old ones and also be willing to attend events like festivals, industry's events, to collaborate and share ideas with others to be able to make good and relevant films $(3,5)$ for its audience. Doing so help them to see missing links in production and gives them better insight of how to come up with superior productions.

Not only that, for her to be an epitome of national development of Nigerian society and culture, the industry must rid itself of tribal and sectional sentiments that has come to characterized the Nigerian socio-political system of the Nigerian society, if she must be a tool to be reckoned with in national development. Doing so will help her to engage brains from all worth of life and culture in Nigeria into the industry regardless of their tribal and geographical location. When people from different backgrounds are brought into the industry, they bring in their experiences, values and cultures into the making of the industry to a viable industry, which promotes the rich cultural heritage of the nation thus boosts its socially, economically and politically.

Lastly, the industry must as a matter of urgency retrace her steps towards the right direction to arrest the social, political, cultural, religious, moral and economic decay that the Nigerian society has sank into, due to the promotion of values and cultures that are harmful to it. She should embark on productions that feature heroes and heroines of our great nation and societies, and also produce films that centered on communalism, respect of elders and authorities, respect for sex, marriage and family life, truth and honesty, stewardship, accountability, transparency as well as respect for what is sacred. This will go a long way in projecting the image of Nigerian society positively instead of the culture of corruption, immorality, immodesty and impunity that the industry portrays to the international communities.

\section{Conclusions}

In conclusion, there is still great hope and excellent future for the Nigerian film for industry. The sky is the limit because the industry is indeed a "potentials gold mine" given the scenario where Nigeria as a nation is extremely rich in human resources and cultures. It has quite rich and diverse ethnic groups with their rich cultures which are rich potential for initiative, creativity and innovation in film business. They should explore those areas to curve out a name for themselves and present the true identity of Nigerians because Nigeria is not made up of only Igbo, Yoruba and Hausa-Fulani, what about $98.9 \%$ of the minor tribes in Nigeria that form the bulk of Nigerian tribes even with these three put together? Not only that, not everything about the Igbo, Yoruba and Hausa- Fulani cultures are bad as portrayed by the industry, in fact, there and overwhelming good cultural values from these tribes which need to be explored in the industry.

\section{REFERENCES}

[1] Dr Yosi Apollos Maton is the immediate past Deputy Provost of the Theological Colege of Northern of Northern Nigeria (TCNN), Bukuru, Plateau State of Nigeria from 2013 to 2017. She has bagged PhD in Christian Ethics with a Minor in Pastoral Counselling at the Nigerian Baptist Seminary Ogbomosho, Oyo State of Nigeria in 2012. She has served in various capacities both in the college, Church and society. She is currently teaching Christian ethics both in the undergraduate and post graduate level at TCNN; and is a full member of TCNN faculty.

[2] Theological College of Northern Nigeria (TCNN), Bukuru, is an affiliate of the University of Jos, Plateau State of Nigeria. The University of Jos is a federal University. It is situated in Jos North Local Government of Plateau State, Nigeria. The seminary is an ecumenical school with fifteen churches as the proprietors and two associate members, Anglican Communion and Presbyterian Church of Nigeria. TCNN is located at Jos Local Government

[3] Gambari Ibrahim A. The challenges of nations building: the case of Nigeria. First year anniversary lecture of Mustapha Akanbi foundation, Sharton Hotel Abuja, Nigeria, 7th February 2008 [cited 2016 May 19]. Available from: www.mfng.org/anniversary/challenges-nations-building-ni geria.htm

[4] Madiebo Alexander A. The Nigerian revolution and biafran war. Enugu: Fourth Dimension Pub; 1980

[5] Boer Jan H. Heralds of capitalism or Christ? Ibadan: Day Star Press; 1984

[6] Burns Sir Alan. History of Nigeria. London: George Allen and Unwin Ltd; 1929

[7] Geopolitical zones of Nige Archived copy: (retrieved 2015-07-27) [cited 2016 May 10]. Available from: https://en.wikipedia.org/wiki/Geopolitical_zones_of_nigeri

[8] Somunmi Zents Kunle. Full list of all 371 tribes in Nigeria, states where they originate.(2017 May 10) [cited: 2017 June $\left.4^{\text {th }}\right]$. Available from:

https://www.vanguardngr.com/2017/05/full-list-of-all-371in-nigeria-states-where-they-originate/see also Lewis $\mathrm{M}$. Paul, Gary F. Simons, Charles D. Fenning, eds (2016) "Nigeria" Ethnologue: language of the world $\left(19^{\text {th }} \mathrm{ed}\right)$. Dallas: SIL international Publications [Cited: 2017 November $\left.10^{\text {th }}\right]$. Available from: Culture of Nigeria: https://en.wikipedia.org/wiki/culture of nigeria

[9] Meek C.K. Tribal studies in northern Nigeria Vol. one. London: Kegan Paul, Trench, Trubner and Co; np

[10] Crowder Micheal. The story of Nigeria. London: Faber and Faber; 1966

[11] Adandele E. A. Nigerian historical studies. London: Frank Cass and Company Limited; 1979

[12] Adenugba Olushola Oladele. The role of film in national development (2008) [cited: 2016 May $20^{\text {th }}$ ]. Available from: filminnaija.blogspot.com.ng/2008/06/role-of-film-in-natio 
nal-development.html

[13] Dali Rebecca S. "History and impact of technology on communication and media, and its effects on the Nigerian society": globalization, technology, HIV/AIDS and theological education in Africa Deji Ayegboyin et al (eds). Ibadan: Sceptre Prints; 2010

[14] Yunis A. Film as nation building: the UAE goes into movie business. CINEJ cinema Journal Vol. 3 no. 2 (2014), [cited: 2016 May $20^{\text {th }}$ ]. Available from : https://cinej.pitt.edu/ojs/index.php/cinej/article/view/98/27 1

[15] Okoye Kingsley. Nigeria's film industry and nation building. Nigeria: NAN (2014). [Cited: 2016 June $15^{\text {th }}$ ]. Available from:

www.peoplesdailyng.com/nigerias-film-industry-and-natio n-building/

[16] Dias Mario Saturnino. "Can cinema be a tool for evangelization?" evangelization and social communication. Jacob S. J. Strampickal (ed). Mumbai: Saint Paul society; 2000.

[17] Moudio Rebecca. Nigeria's film industry: a potential gold mine? United Nations African Renewal (May 2013), [Cited: 2016 April $28^{\text {th }}$ ]. Available from:

www.un.org/africarenewal/magazine/may/2013/nigeria's-f ilm-industry-potential-gold-mine

[18] Onishi Norimitsu. Nigeria's booming film industry redefines African life. (2016 February $19^{\text {th }}$ ), [Cited: 2016 May $\left.20^{\text {th }}\right]$. Available

from:https://www.nytimes.com/2016/02/19/world/africa/w ith-a-boom-before-the-cameras-nigeria-redefines-africa-lif e.html
[19] George Menta's TV Series: Cock crows at dawn (2012 April $\left.27^{\text {th }}\right)$, [Cited: 2016 May 21 ${ }^{\text {st }}$. Available from : https://www.google.com/search?q=film+director+of+nolly wood + movie + cock-crows-at-dawn

[20] Ume-Nwagbo Ebele N. E. "Cock crows at dawn": a Nigerian experiment with television drama in development-communication. Netherlands: Marinu Nijhoff Publishers, Gazette 37 (1986), [Cited: 2016 January 20 ${ }^{\text {th }}$ ]. Available from: International Communication Gazette: journal.sagepub.com/doi/abs/10.1177/0016549286037003 03

[21] Girls trafficking for prostitution2-2017 Nollywood movie 2017. [Cited: 2017 July $20^{\text {th }}$ ]. Available from :https://www.google.com.ng/search?q=the/trafficker

[22] MbaEmeka. NEClive: read EmakaMba's speech on building a sustainable Nollywood industry.NET News (2014), [Cited: 2016 June 25 ${ }^{\text {th }}$. Available from:thenet.ng/neclive-read-emeka-mbas-speech-on-buildi ng-a-sustainable-nollywood-industry

[23] Maton Yosi A. D. "The implications of globalization and Technology on the Nigerian Society": Globalization, Technology, HIV/AIDS and Theological Education in Africa. Deji Ayegboyin Et al (eds). Ibadan: Sceptre Prints, 2010

[24] Madichie N.O. The Nigerian movie industry "Nollywood"a near perfect marketing case study.(2010), [Cited: 2016 May $\left.15^{\text {th }}\right]$. Available

from:https://www.econbiz.de/......./the-nigerian-movie-in dustry-nollywood-a-nearly-perfect-marketing-case-study

[25] Price J. H. Political Institutions of West Africa.n.d. 